\title{
PARTICLE IMAGE VELOCIMETRY TECHNIOUE AND ULTRASOUND METHOD TO OBTAIN THE MODULUS OF ELASTICITY OF Bertholletia excelsa WOOD
}

\author{
Eduardo Hélio de Novais Miranda, \\ https://orcid.org/0000-0002-3156-658X \\ Rayner Pathele Ferreira ${ }^{2}$ \\ https://orcid.org/0000-0002-5123-6246 \\ Rodrigo Allan Pereira ${ }^{3}$ \\ https://orcid.org/0000-0002-1628-1172 \\ Taiane Oliveira Guedes ${ }^{1}$ \\ https://orcid.org/0000-0003-2865-1406 \\ Fernando Pujaico Rivera ${ }^{2}$ \\ https://orcid.org/0000-0002-4970-2818 \\ Diogo Antonio Correa Gomes ${ }^{1}$ \\ https://orcid.org/0000-0003-3967-4574
}

\begin{abstract}
Non-destructive techniques for characterizing materials in-service have been increasing in importance. Thus, it is relevant to assess the potential of non-destructive techniques for solid materials. This work aimed to determine the modulus of elasticity of Bertholletia excelsa wood using the particle image velocimetry technique and the ultrasound method to compare the results with the conventional methodology. For this purpose, samples of Bertholletia excelsa were made using a circular saw. The samples were evaluated for sound propagation to calculate the modulus of elasticity using ultrasound equipment. Subsequently, they were subjected to the compression parallel to grain test in a universal testing machine. The samples were marked and monitored during the loading session, with the repeated capture of images using a professional camera. The deformation values obtained were used to estimate the modulus of elasticity using the particle image velocimetry technique. The mean values of modulus of elasticity found were $17403 \mathrm{MPa}$ for ultrasound, $15589 \mathrm{MPa}$ for the particle image velocimetry technique, and $15333 \mathrm{MPa}$ for the universal testing machine. The particle image velocimetry technique was considered to be statistically similar (Tukey $\alpha=0,05$ ) to the other methods tested. The linear coefficient of determination $\left(\mathrm{R}^{2}\right)$ between the particle image velocimetry technique and the universal testing machine was 0,95 , a high and satisfactory value. Thus, the particle image velocimetry technique and the ultrasound method are valid to estimate the modulus of elasticity of Bertholletia excelsa wood and possibly of woods with similar technological characteristics.
\end{abstract}

Keywords: Characterization of materials, conventional method, mechanical property, non-destructive techniques, particle image velocimetry.

\footnotetext{
${ }^{1}$ Universidade Federal de Lavras, Departamento de Ciências Florestais, Lavras, Brasil.

${ }^{2}$ Universidade Federal de Lavras, Departamento de Engenharia, Lavras, Brasil.

${ }^{3}$ Universidade Federal de Lavras, Departamento de Engenharia Agrícola, Lavras, Brasil.

•Corresponding author: eduardohelio013@gmail.com
}

Received: 14.06.2021 Accepted: 01.12.2021 


\section{INTRODUCTION}

Conventional testing techniques used to analyze physical and mechanical properties of materials, such as the modulus of elasticity, usually require high processing time, specific equipment, a large number of samples and cause permanent damage to the material tested, making it unusable. Thus, non-destructive testing techniques become an option to determine the properties of materials in-service, usually requiring shorter application time and cost when compared to destructive tests (Pereira et al. 2019, Zahedi et al. 2020).

Among the non-destructive testing techniques, the Particular Image Velocimetry (PIV) technique and the ultrasound method stand out, as they are considered simple and fast tests. The Particle Image Velocimetry technique originated from the gaseous materials study field (Raffel et al. 2018). The technique was adapted to study the movement of solid materials through the analysis of images captured from samples marked with random points, at first using a laser (Braga-Júnior et al. 2015) and, more recently, using ink particles drawn on the sample surface (Pereira et al. 2019, Novosel et al. 2021). The time gap between photos is predefined and must contemplate the changes that occur in the material during the load application. These images are processed in a computational algorithm that calculates the displacement that occurred on the surface of the studied object (Pereira et al. 2019).

Guedes et al. (2019) determined the modulus of elasticity of Cedrela spp. and Eucalyptus cloeziana wood submitted to static flexion using the PIV technique. The authors found the technique results satisfactory when compared with the conventional method. Pereira et al. (2019) also evaluated the use of the PIV technique to measure the deformations of solid materials in wood panels of Pinus oocarpa, Eucalyptptus grandis, plywood, laminated veneer lumber (LVL) and oriented strand board (OSB) subjected to static flexion. Obtained values were statistically equal to those of conventional methods. Therefore, even not allowing a three-dimensional correlation of images resulting from the tests, as occurs in the Digital Image Correlation (DIC) technique, the PIV technique has been showing satisfactory results in solid materials (Peters et al. 1983).

Ultrasound is a technique that uses the propagation of sound created by high-frequency waves to evaluate solid materials. Variations in the propagation speed of waves emitted by ultrasound are captured by the equipment and generate information that makes it possible to determine the modulus of elasticity of the material. Studies using different wood species aiming to estimate physical and mechanical properties by the ultrasound technique have been carried out, and satisfactory results have been found (Gonçalez et al. 2001, Ribeiro et al. 2013).

To work with a biological, heterogeneous, and anisotropic material such as wood which is of great importance in civil construction requires many studies. Furthermore, Brazil, according to the United Nations (UN) for the Agriculture and Food (FAO 2015), is the second largest wood product of Bertholletia excelsa in the world, a complex wood species that needs to be better characterized. Thus, innovative techniques such as the PIV technique for solids and the ultrasound method must be tested in this and in different other wood species and different types of materials.

In this context, studies are perceived as incipient, especially those that present a combination of two non-destructive techniques for the characterization of solid materials, and the research is justified by the attempt to consolidate two recent methodologies as simple, fast and reliable tests in comparison with a conventionally used method.

This work aimed to determine the modulus of elasticity of the medium density wood Bertholletia excelsa using the non-destructive techniques Particle Image Velocimetry and ultrasound method as measurement tools.

\section{MATERIAL AND METHODS}

\section{Material preparation}

This study used timbers of Bertholletia excelsa, obtained from an experimental planting at the Federal University of Lavras (UFLA) from 20 years-old trees. The samples for the compression parallel to grain test and the ultrasound test were prepared according to the ABNT NBR 7190 (2010). A total of 30 specimens with dimensions of $100 \mathrm{~mm}$ by $25 \mathrm{~mm}$ by 25 were conditioned in climate at $22{ }^{\circ} \mathrm{C} \pm 2{ }^{\circ} \mathrm{C}$ and $65 \% \pm 5 \%$ relative 
humidity (RH) until they reach a moisture content of $12 \% \pm 1 \%$. Density value of beech specimen was measured as $587 \mathrm{~kg} / \mathrm{m}^{3}$. The trees have an average diameter of $540 \mathrm{~mm}$. The proportion of heartwood and sapwood was the same for the samples and all were taken from the same batch.

\section{Ultrasound test}

The speed of propagation of the sound wave through the specimen, in the longitudinal direction, was measured by the ultrasound equipment (Ultrasonic-Test BP-7) with $45 \mathrm{kHz}$ transducers. Through this information, the modulus of elasticity was calculated (Equation 1) ABNT NBR 15521 (2007).

$$
M O E=V^{2} \rho
$$

In which:

$$
\begin{aligned}
& \text { MOE }=\text { Modulus of elasticity }(\mathrm{Pa}) \\
& \mathrm{V}=\text { Propagation speed of the wave }\left(\mathrm{m} \cdot \mathrm{s}^{-1}\right) \\
& \rho=\text { Apparent density }\left(\mathrm{kg} / \mathrm{m}^{3}\right)
\end{aligned}
$$

The equipment was calibrated with a standard acrylic sample before each test.

\section{Compression parallel to grain in the universal testing machine}

The samples went through the compression parallel to the grain test in a universal testing machine (EMIC DL-30000), with the capacity of 30 tons-force and speed of $1 \mathrm{~mm} / \mathrm{min}$ (adapted from the ABNT NBR 7190 (2010) until the specimens reached the breaking point, finishing the test.

\section{Estimation of the modulus of elasticity by the PIV technique}

The PIV technique was performed simultaneously with the compression parallel to the grain test. For the PIV algorithm analysis, it was necessary to mark the samples with ink dots, randomly distributed over their entire surface. Thus, consecutive images were captured during the loading session. The professional camera (Sony alpha a330 10,4 megapixels) was positioned perpendicularly to the sample surface, at approximately $25 \mathrm{~cm}$ distance (Figure 1). The procedure started with the capture of the image at zero seconds. Subsequently, the capture was performed every 30 seconds, from the activation of the Universal Testing Machine until the rupture of the samples. The average time of each trial was $7 \mathrm{~min}$.

With the strain values obtained by the PIV technique, the loads applied by the universal testing machine and the geometric characteristics of the cross-section, it was possible to calculate the modulus of elasticity of the samples tested. It should be noted that the standard ABNT NBR 7190 (2010) was used as a reference (Equation 2).

$$
M O E=\left(\frac{\sigma_{50 \%}-\sigma_{10 \%}}{\varepsilon_{50 \%}-\varepsilon_{10 \%}}\right)
$$

In which:

MOE $=$ Modulus of elasticity $(\mathrm{MPa}) ;$

$\sigma=$ Stress $(\mathrm{MPa}) ;$

$\varepsilon=$ Specific deformation. 


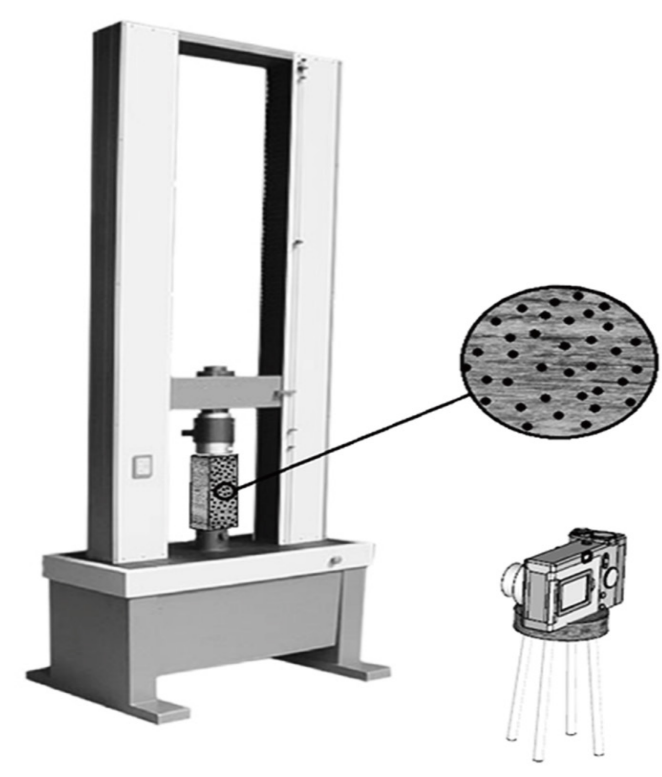

Figure 1: Setup of the PIV method and the compression test.

\section{Data analysis}

Descriptive statistics analysis and Tukey test $(\alpha=0,05)$ were used to compare the means of the modulus of elasticity obtained by the PIV technique, the conventional technique and the ultrasound method. In addition, regression analysis was also performed between the methods.

\section{RESULTS AND DISCUSSIONS}

The values of modulus of elasticity obtained by each test method can be seen in Figure 2. The mean values of sound wave propagation speed, measured by the ultrasound equipment, and apparent density of the specimens were $5038,79 \mathrm{~m} / \mathrm{s}$ and $684 \mathrm{~kg} / \mathrm{m}^{3}$, respectively. Visually, the amplitude of the values for the techniques is similar. However, the absolute results by the ultrasound method were superior to those obtained by the other two techniques. According to Stangerlin et al. (2011), the induced stress in dynamic tests is reduced, that is, dynamic measurements are based on mechanical properties only in the elastic limit and therefore this method depends on physical characteristics of materials, such as density, moisture, and presence of imperfections inside the tested materials. The PIV technique has the advantage, in this sense, of evaluating only the surface of the tested material, not depending on the physical properties of the material. Thus, it was able to follow the displacements of the specimens from the beginning to the end of the test, including at the moment of rupture. 


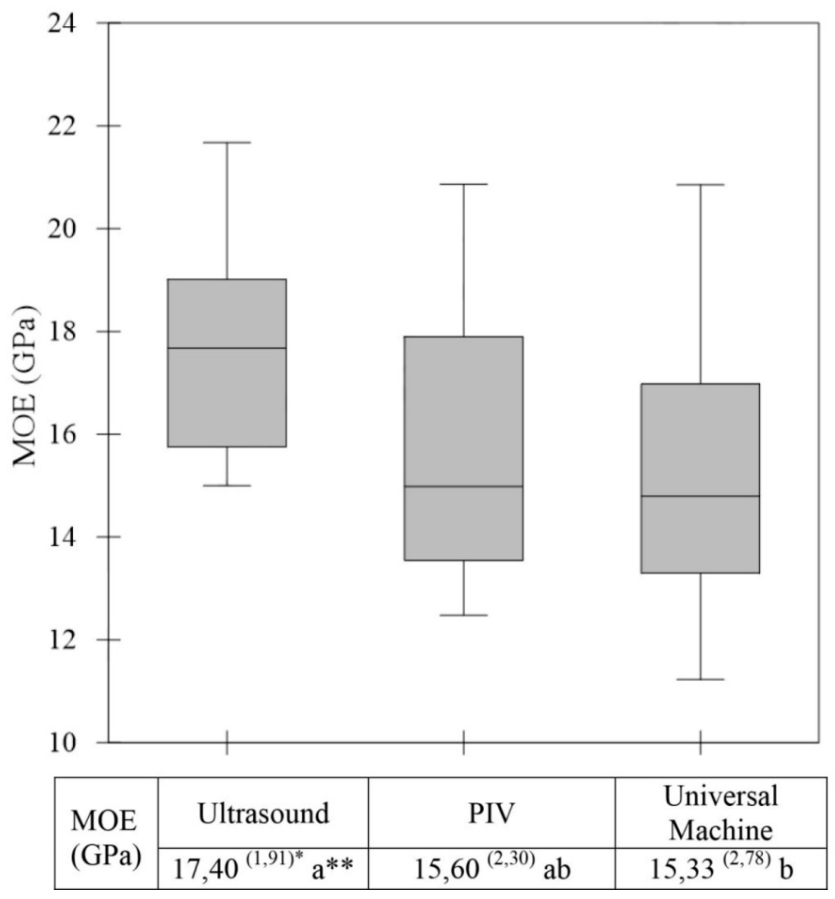

Figure 2: Range of values and descriptive statistics of Bertholletia excelsa modulus of elasticity (MOE) obtained by the Particle Image Velocimetry (PIV) technique, ultrasound method, and conventional method, using a universal testing machine.

*Standard deviation of means.

***Means followed by the same letter in the column do not differ at $5 \%$ probability by the Tukey test.

The mean values for modulus of elasticity were $17403 \mathrm{MPa}$ for the ultrasound method, $15589 \mathrm{MPa}$ for the PIV technique, and $15333 \mathrm{MPa}$ for the universal testing machine. The values found corroborate with other researches with the species Bertholletia excelsa. Thus, for example, Petrechen and Ambrósio (2016), Jesus et al. (2015) and Souza (2016) obtained values, respectively, of $18220 \mathrm{MPa}, 14881 \mathrm{MPa}$ and $13474 \mathrm{MPa}$ for the modulus of elasticity in the compression parallel to the grain test, using the universal testing machine.

According to the Tukey test $(\alpha=0,05)$ there is no statistical difference between the PIV technique results and those found with for the ultrasound method and those found with for the conventional method. This result implies that the PIV technique is interesting to make estimations. Its results are similar to those found with the method already used in the standard (universal testing machine). As it is also similar to the ultrasound technique, another non-destructive method, the results of this work are quite satisfactory. Figure 3 shows the linear regression to verify the relationship between the methods. 


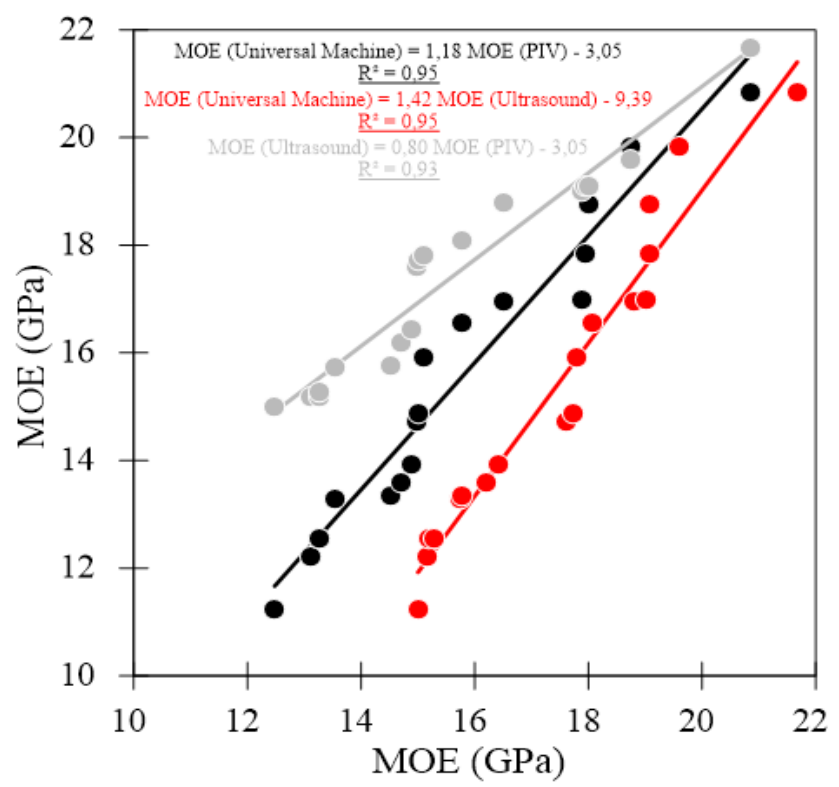

Figure 3: Linear regression between the modulus of elasticity (MOE) values of Bertholletia excelsa wood.

The coefficient of determination between the PIV technique and the universal testing machine was 0,95. Thus, the PIV technique can estimate results for the modulus of elasticity that will be very close to the values determined by the universal testing machine. Furthermore, the coefficient of determination between the PIV technique and the ultrasound and between the ultrasound and the universal testing machine were 0,93 and 0,95, respectively, equally high values. These results validate the two recent non-destructive techniques as simple, fast and reliable tests, in comparison with a conventionally used method, for the wood studied and probably for woods with similar technological characteristics.

Other research has already proven the efficiency of the PIV technique and ultrasound method, compared to conventional methodologies, to estimate physical or mechanical parameters in wood (Pereira et al. 2019, Guedes et al. 2019, Gonçalez et al. 2001, Ribeiro et al. 2013).

\section{CONCLUSIONS}

The PIV technique was considered to be statistically similar (Tukey $\alpha=0,05$ ) to the ultrasound and standard method. The mean values of modulus of elasticity obtained by the three techniques, ultrasound method, PIV technique and universal testing machine, were $17403 \mathrm{MPa}, 15589 \mathrm{MPa}$ and $15333 \mathrm{MPa}$, respectively. The linear coefficient of determination $\left(\mathrm{R}^{2}\right)$ between the PIV technique and the universal testing machine was 0,95 a high and satisfactory value. Thus, the PIV technique and the ultrasound method are valid to estimate the modulus of elasticity of Bertholletia excelsa wood and possibly of woods with similar technological characteristics. 


\section{REFERENCES}

ABNT NBR. 2010. Projeto de estruturas de madeira. ABNT NBR. 7190. 2010. https://www.abntcatalogo. com.br/norma.aspx?ID=3395

ABNT NBR. 2007. Ensaios não destrutivos - Ultra-som - Classificação mecânica de madeira serrada de dicotiledôneas. ABNT NBR. 15521. 2007. NBR: Rio de Janeiro, RJ, Brazil. https://www.abntcatalogo.com. br/norma.aspx? ID $=317$

Braga-Júnior, R.A.; Magalhães, R.R.; Melo, R.P.; Gomes, J.V. 2015. Maps of deformations in a cantilever beam using particle image velocimetry (PIV) and speckle patterns. Rev Esc Minas 68(3): 273-278. http://dx.doi.org/10.1590/0370-44672013680016

FAO. Food and Agriculture Organization of the United Nations. 2015. Statistics 2014. http://www.fao.org/statistics/en/

Gonçalez, C.J.; Valle, D.A.; Costa, F.A. 2001. Estimativas das constantes elásticas da madeira por meio de ondas ultra-sonoras (ultra-som). Cerne 7(2): 81-92. http://www.redalyc.org/articulo.oa?id=74470208

Guedes, T.O.; Pereira, R.A.; Rivera, F.P.; Silva, J.R.M. 2019. Particle image velocimetry for obtaining the young's modulus in woods. Cerne 25(2): 240-245. http://www.cerne.ufla.br/site/index.php/CERNE/article/ view/2115

Jesus, J.M.H.; Longsdon, N.B.; Finger, Z. 2015. Classes de Resistência de Algumas Madeiras de Mato Grosso. J Eng Sci 1(3): 35-42. https://doi.org/10.18607/ES201531

Novosel, A.; Sedlar, T.; Čizmar, D.; Turkulin, H.; Živković, V. 2021. Structural reinforcement of bi-directional oak-wood lamination by carbon fibre implants. Constr Build Mater 287(2021): 123073. https://doi.org/10.1016/j.conbuildmat.2021.123073

Pereira, R.A.; Gomes, F.C.; Braga Jr, R.A.; Rivera, F.P. 2019. Displacement measurement in sawn wood and wood panels beams using the particle image velocimetry. Cerne 25(1): 110-118. https://doi.org/10.1590/01047760201925012619

Peters, W.H.; Ranson, W.F.; Sutton, M.A.; Chu, T.C.; Anderson, J. 1983. Application of digital correlation methods to rigid body mechanics. Opt Eng 22(6): 232-244. https://doi.org/10.1117/12.7973231

Petrechen, G.P.; Ambrósio, J.D. 2016. Preparação e caracterização mecânica de compósitos de polipropileno com resíduos lignocelulósicos da castanha do brasil (Bertholletia excelsa). In Congresso Brasileiro de Engenharia e Ciência dos Materiais, Natal, Brazil. http://www.metallum.com.br/22cbecimat/anais/

Raffel, M.; Willert, C.E.; Scarano, F.; Kähler, C.J.; Wereley, S.T.; Kompenhans, J. 2018. Particle image velocimetry. Springer International Publishing AG. https://doi.org/10.1007/978-3-319-68852-7

Ribeiro, G.P.; Gonçalez, C.J.; Gonçalvez, R.; Teles, F.R.; Souza, F. 2013. Ultrasound waves for assessing the technological properties of Pinus caribea var hondurensis and Eucalyptus grandus wood. Maderas-Cienc Tecnol 15(2): 195-204. http://dx.doi.org/10.4067/S0718-221X2013005000016

Souza, M.N. 2016. Volumetria e qualidade da madeira de Bertholletia excelsa em plantios na amazônia central. Master Thesis, Federal University of Amazonas, Manaus, Brazil. https://www.alice.cnptia.embrapa.br/ alice/bitstream/doc/1106937/1/Marrieth.pdf

Stangerlin, D.M.; Cademartori, P.H.G.; Gatto, D.A.; Melo, L.C.R.R.; Vivian, M.A.; Modes, K.S. 2011. Propagação indireta e semidireta de ondas ultrassonoras na estimativa de propriedades mecânicas da madeira. Cienc Madeira 2(2): 85-95. https://periodicos.ufpel.edu.br/ojs2/index.php/cienciadamadeira/article/ view/4032/3176 
Zahedi, M.; Najafi, S.K.; Füssl, J.; Elyasi, M. 2020. Characterization of Engineering Elastic Parameters of Oriented Strand Board (OSB) Manufactured from Poplar (Populus deltoides) Strands Using Ultrasonic Contact Pulse Transmission. Drvna industrija 71(3): 227-234. https://doi.org/10.5552/drvind.2020.1908 